American Journal of Pharmaceutical Education 2019; 83 (9) Article 7785.

\title{
COMMENTARY
}

\section{Writing and Thinking}

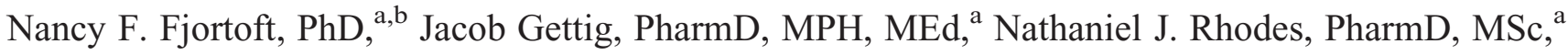 \\ Marc Scheetz, PharmD, MSc ${ }^{\mathrm{a}}$ \\ ${ }^{a}$ Midwestern University Chicago College of Pharmacy, Chicago, Illinois \\ ${ }^{\mathrm{b}}$ Associate Editor, American Journal of Pharmaceutical Education, Arlington, Virginia
}

Submitted July 30, 2019; accepted August 6, 2019; published November 2019.

There has been a steady stream of evidence linking pre-pharmacy grade point averages, Pharmacy College Admission Test (PCAT) composite scores, and certain PCAT subtest scores to student success in pharmacy school, especially with regard to early didactic performance such as in the first professional year. ${ }^{1}$ The largest multi-institutional study ${ }^{2}$ of predictors of academic success, which included 22 colleges of pharmacy and over 2,000 student records, found that most PCAT subtest scores and pre-pharmacy grade point average (GPA) collectively explained $25 \%$ of the variance in students' first professional year GPA. However, the PCAT writing scores, while positively correlated with first professional year GPAs, did not contribute to the regression model.

In a recent internal analysis exploring predictors of failing one or more courses in the first professional year at Midwestern University Chicago College of Pharmacy, we identified that lower Pharmacy College Admission Test (PCAT) writing scores predicted a higher failure rate for at least one course $(p=.01)$. PCAT writing score was tied for the most impactful variable in the logistic model. Other significant variables that predicted failure were lack of previous bachelor's degree $(p=.01)$, and PCAT biology score $(p=.02)$. Those who scored 0 or 1 had a failure rate of $33 \%$, whereas those who scored 3 or higher had a failure rate below $10 \%$. Further, those scoring at least 4 had only a $3 \%$ failure rate. Thus, failures decreased with each increase in PCAT writing score.

The link between writing and student success deserves more thought and exploration. The PCAT writing score represents an average of two scores, one for conventions of language (eg, grammar, sentence structure) and the other for problem-solving. The problem-solving construct of the PCAT writing score includes the ability to state the problem, provide sufficient support and details about the problem, determine one or more possible solutions, and sufficiently support the best solution to the problem. The scores can range from 1

Corresponding Author: Nancy Fjortoft, Midwestern University Chicago, College of Pharmacy, Chicago, IL, 60515. Tel: 630-971-6417.E-mail:NFJORT@midwestern.edu. (inadequate) to 6 (superior), but students can receive a score of 0 if they refuse to respond or write their response in a language other than English. ${ }^{3}$ Approximately $82 \%$ of PCAT test-takers earn a PCAT writing score at or above 3.0; whereas, only about $3 \%$ earn a PCAT writing score at or above 4.5 .

The problem-solving construct of the PCAT writing score involves a degree of critical thinking, which has long been a focus of pharmacy education and practice. A recent search in the American Journal of Pharmaceutical Education found 1,107 articles in which critical thinking was prominent. Critical thinking can be defined as "the intellectually disciplined process of actively and skillfully conceptualizing, applying, analyzing, synthesizing, and/or evaluation information gathered from, or generated by, observation, experience, reflection, reasoning, or communication as a guide to belief and action." Critical thinking goes well beyond the acquisition and retention of knowledge or information. It requires a reasoned and rational approach to gathering, evaluating, and using information.

Well-known historian and writer David McCullough once stated, "Writing is thinking. To write well is to think clearly. That's why it's so hard." Writing requires observation, reflection, analysis, and selecting and presenting information. Writing requires one to clearly state ideas and present evidence to support those ideas, processes that are fundamental to critical thinking.

Several studies have demonstrated the link between writing and critical thinking. A recent study explored the relationship between writing and critical thinking performance in a general education biology course using a pretest/post-test control group design. The investigators compared critical thinking scores using the California Critical Thinking Skills Test, which has been validated as an objective measure of undergraduate and graduate level college students' critical thinking skills. The experimental group of students were required to complete a post-laboratory writing assignment. The control group of students completed the standard post laboratory quiz. Results indicated that the critical thinking scores of students in the writing group significantly improved 


\section{American Journal of Pharmaceutical Education 2019; 83 (9) Article 7785.}

compared to the scores of students in the standard group. ${ }^{7}$ Another study of physiology students found that students who participated in a required writing assignment with peer review performed better on learning assessments (examinations) than those students who did not. ${ }^{8}$

In pharmacy education, much of the focus on writing has been on reflective writing in portfolios. For example, Briceland and Hamilton examined the utility of an electronic portfolio with self-reflective essays and evidence to demonstrate achievement of outcomes. ${ }^{9}$ Hobson and colleagues describe a capstone course using a portfolio and a written self-assessment of student achievement of curricular outcomes. ${ }^{10}$ Tsingos-Lucas and her team have written extensively on reflective thinking and writing. Reflective writing includes some of the elements of critical thinking such as observation and conceptualizing, but also includes an analysis of emotions and an inward exploration of feelings and behaviors. They recently found that reflective writing skills were a predictor of academic success in certain learning assessment formats. ${ }^{11}$

In a recent review article, Persky and colleagues describe elements of critical thinking and existing barriers and challenges to developing students' critical thinking skills, and offer suggestions for curricular, course-level, and environmental changes that could increase students' critical thinking abilities. They propose a four-step cycle: generation, conceptualization, optimization, and implementation. ${ }^{12}$ Writing essays, patient care plans, and commentaries such as this capture these four steps and embody all the elements of critical thinking.

The question then is why do we as pharmacy educators not require more writing from our students? There may be several reasons. First, as faculty members, we often teach as we were taught, which historically meant listening to lectures, taking examinations which typically were in multiple-choice type format, and generally relying on the acquisition of factual knowledge. Second, grading writing assignments is more time intensive than grading traditional examinations, and faculty members may lack the expertise to provide appropriate constructive feedback on students' writing. Third, pharmacy students do not typically like or appreciate writing assignments. Many colleges rely heavily on students' course and instructor evaluations in the faculty performance review process, so faculty members may fear lower instructor evaluations if they incorporate writing assignments among their assessments.

Given the growing evidence linking writing to critical-thinking skills and academic success, our recommendations are twofold. Colleges of pharmacy should consider using the writing component of the PCAT in their admissions decisions. Second, throughout the PharmD curriculum, colleges should require students to complete writing assignments that go beyond self-assessments and reflective statements. For example, require students to address in writing a controversy such as an ethical dilemma faced in practice or the off-label use of a medication. Require students to make a statement and include evidence supporting their stance, in other words, the practice of written argument and persuasion. Concurrently, faculty members need to appreciate the link between writing and thinking, and develop the skills needed to effectively assess students' writing skills and provide constructive and actionable feedback to students.

\section{REFERENCES}

1. Meagher DG, Pan T, Wegner R et al. PCAT Reliability and Validity. NCS Pearson, Inc. http://pcatweb.info/downloads/Faculty/ PCATReliabilityandValidity.pdf. Published 2016. Accessed 2019 May.

2. Meagher DG, Pan T, Perez CD. Predicting performance in the first-year of pharmacy school. Am J Pharm Educ. 2011;75(5):Article 81. https://doi.org/10.5688/ajpe75581.

3. Meagher DG, Pan T, Wegner R et al. Interpreting PCAT Scores. NCS Pearson, Inc. http://pcatweb.info/downloads/Faculty/ Interpreting_PCAT_Scores.pdf Published 2016. Accessed 2019 May. 4. Meager D. Understanding and interpreting pharmacy college admission test scores. Am J Pharm Educ. 2017;Feb 25; 81(1): 17. doi: 10.5688/ajpe81117.

5. The Foundation for Critical Thinking. Defining Critical Thinking. https://www.criticalthinking.org/pages/defining-critical-thinking/ 766. Accessed May 9, 2019

6. McCullough D. David McCullough Quotes. https:// www.goodreads.com/author/quotes/6281688.David_McCullough. Accessed May 9, 2019.

7. Quitadamo IJ, Kurtz, MJ. Learning to improve: using writing to increase critical thinking performance in general education biology. Life Sci Ed. 2017;6(2). Accessed May 7, 2019.

8. Pelaez NJ. Problem-based writing with peer review improves academic performance in physiology. Adv Physiol Ed. 2002;26(1-4) 174-84. Accessed May 7, 2019.

9. Briceland LL, Hamilton RA. Electronic reflective student portfolios to demonstrate achievement of ability-based outcomes during advanced pharmacy practice experiences. Am J Pharm Educ. 201;74(5)Article 79.

10. Hobson EH, Johnston PE, Spinelli AJ. Stating a reflective capstone course to transition pharmd graduates to professional life. Am J Pharm Educ. 2015;79(1)Article 14.

11. Tsingos-Lucas C, Bosnic-Anticevich S, Schneider CR, Smith L. Using reflective writing as a predictor of academic success in different assessment formats. Am J Pharm Educ. 2017;81(1)Article 8. 12. Persky AM, Medina MS, Castleberry AN. Developing critical thinking skills in pharmacy students. Am J Pharm Educ. 2019;83(2) Article7033. 